ХIMIЯ

CHEMISTRY

https://doi.org/10.15407/dopovidi2021.04.077

УдК 538.9533 .9

О.М. Кордубан ${ }^{1}$, https://orcid.org/0000-0003-4401-0203

T.В. Крищук ${ }^{1}$, https://orcid.org/0000-0001-6527-2021

М.М. Медведський ${ }^{2}$

${ }^{1}$ Інститут загальної та неорганічної хімії ім. В.І. Вернадського НАН України, Київ

2 Головна астрономічна обсерваторія НАН України, Київ

E-mail: akord.imp@gmail.com

\title{
Новий метод синтезу наноматеріалів для потреб нанотехнологій
}

Представлено членом-кореспондентом НАН Украӥни В. М. Огенком

Розроблено новий метод синтезу наноматеріалів з використанням електричного вибуху провідників (ЕВП), в якому синтез нанопорошків ЕВП суміщено в часі з іншими синтезами та процесами з метою використання в них синтезованих нанопорошків у реальному часі як надактивних прекурсорів. Вперше безпосередньо з нанопорошків отримано нові типи каталітичних плазмових нанопокриттів $\mathrm{WO}_{3-x} /$ нержавіюча сталь та мезопоруватих фото- та електрокаталітичних нанодисперсних плівок $\mathrm{TiO}_{2-x}$, $\mathrm{TiO}_{2-x} / \mathrm{Ag}_{\text {. }}$ У наноматеріалах нового типу повністю збережено нанодисперсну структуру, а для їх синтезу не використовуються органічні складові. Зменшено температуру проведення реакціі $\mathrm{WO}_{3-x}+3 \mathrm{H}_{2} \mathrm{~S} \rightarrow \mathrm{WS}_{2}+\mathrm{S}_{3}+3 \mathrm{H}_{2} \mathrm{O}$ синтезу $W_{2}$ з 800 до $450{ }^{\circ} \mathrm{C}$ з використанням ЕВП нанопорошків $\mathrm{WO}_{3-x}$ як надактивних прекурсорів. Розроблений метод синтезу наноматеріалів є новим інструментом вирішення задач в області нанотехнологій.

Ключові слова: електричний вибух провідників, нанопорошки, плазмові нанопокриття, нанодисперсні плівки, рентгенівська фотоелектронна спектроскопія.

Електричний вибух провідників (ЕВП) у газовому середовищі - це процес, в якому за дуже короткий час високовольтним імпульсом ( $U=20 \div 30 \mathrm{\kappa}, t=10^{-5} \div 10^{-8}$ с) з густиною струму $10^{4}-10^{6} \mathrm{~A} /$ мм $^{2}$ у металевий провідник вводиться енергія, яка може в кілька разів перевищувати його енергію сублімації. В результаті метал вибухає і розширюється 3 швидкістю $5 \cdot 10^{3}$ м/с з утворенням вибухової хвилі та перетворюється на золь наночастинок 10-100 нм. Швидкість охолодження продуктів вибуху в газовому середовищі на початковому етапі $\left(T=10^{5}{ }^{\circ} \mathrm{C}\right)$ становить $10^{7}{ }^{\circ} \mathrm{C} / \mathrm{c}$, на кінцевому етапі $\left(T=4 \cdot 10^{3}{ }^{\circ} \mathrm{C}\right)-10^{3} \circ \mathrm{C} / \mathrm{c}$. Це призводить до часткового блокування дисипативних процесів і формування кристалічної гратки в нерівноважних умовах та надлишку енергії з появою двійникової структури, ва-

Ци т у в ан н я: Кордубан О.М., Крищук Т.В., Медведський М.М. Новий метод синтезу наноматеріалів для потреб нанотехнологій. Допов. Нащ. акад. наук Укр. 2021. № 4. С. 77-85. https://doi.org/10.15407/ dopovidi2021.04.077 
кансій, розірваних зв'язків [1-3]. Але обумовлена цим висока хімічна активність нанопорошків на практиці не використовується.

Останні 20 років метод ЕВП застосовується для синтезу нанопорошків металів та їх сполук, зокрема, в газовому середовищі. Продуктивність синтезу становить 0,1-0,3 кг/год. Принцип дії всіх установок однаковий - металевий провідник з постійною лінійною швидкістю вводиться у вибухову камеру з газовою атмосферою і з визначеною частотою комутується до батареї конденсаторів. Синтезований нанопорошок виводиться з камери газовим потоком і збирається фільтрами в приймальний бункер. Під час подальшого зберігання в результаті релаксації дефектної структури і пасивації киснем відбувається агломерація та окиснення наночастинок з втратою хімічно активних центрів їх поверхні.

Перевагами методу синтезу нанопорошків із застосуванням ЕВП є відсутність домішок від контактів з розчинниками, прекурсорами, хімічним обладнанням і т. п., відсутність тиглів і використання енергії тільки для нагрівання дроту, відсутність проміжних етапів під час синтезу. Метод отримав розвиток в Росії, Свропі, США, Індії, Китаї.

Основним недоліком методу є невикористання високої початкової хімічної активності нанопорошків, яка обумовлена нерівноважними умовами їх синтезу і швидко зникає під дією релаксаційних процесів.

Нами вперше розроблено та реалізовано новий метод синтезу з використанням ЕВП, в якому процес синтезу нанопорошків суміщено в часі з зовнішніми синтезами і процесами 3 метою використання в них синтезованих нанопорошків як надактивних прекурсорів, при цьому забезпечено доставку цих нанопорошків у інертному середовищі назовні, в зону реакцій, протягом кількох десятків секунд або миттєво. Якщо в класичному синтезі з використанням ЕВП кінцевим продуктом є нанопорошки, то в новому методі синтез нанопорошків є проміжним етапом, а кінцевим етапом є синтез наноматеріалів.

Розроблений метод синтезу наноматеріалів з використанням ЕВП є новим інструментом для вирішення задач в області нанотехнологій. У науковій літературі аналогічних рішень немає.

У результаті реалізації нового методу синтезу отримано наноматеріали нових типів: плазмові нанопокриття для каталітичних застосувань і наноплівки для виготовлення активних та фотоактивних елементів сенсорів, у яких повністю збережено нанодисперсну структуру і які вільні від органічних зв’язуючих, карбідних і гідроксидних фаз, хлору та фтору. Також показана можливість зниження температури класичних хімічних реакцій 3 використанням у них як надактивних прекурсорів ЕВП нанопорошків.

Для реалізації задач дослідження було розроблено та створено оригінальне обладнання: установку із синтезу нанопорошків ЕВП, яка складалася з вибухової камери, високовольтного блока живлення, систем напуску та очищення газів, форвакуумної системи; електротермічний плазмовий прискорювач з високовольтним блоком живлення для напилення покриттів спрямованим електричним вибухом; установку для напилення нанопорошків 3 використанням мікроплазмотрона. Рентгенівська фотоелектронна спектроскопія (РФС) використовувалась як один з елементів процесу керованого синтезу [4]. Методом РФС проводився контроль зарядових станів поверхні, які відповідали максимальному ступеню дефектності нанопорошків, з метою визначення в реальному часі оптимальних енергетичних режимів електричного вибуху. В цілому, методика експерименту була спрямована на 

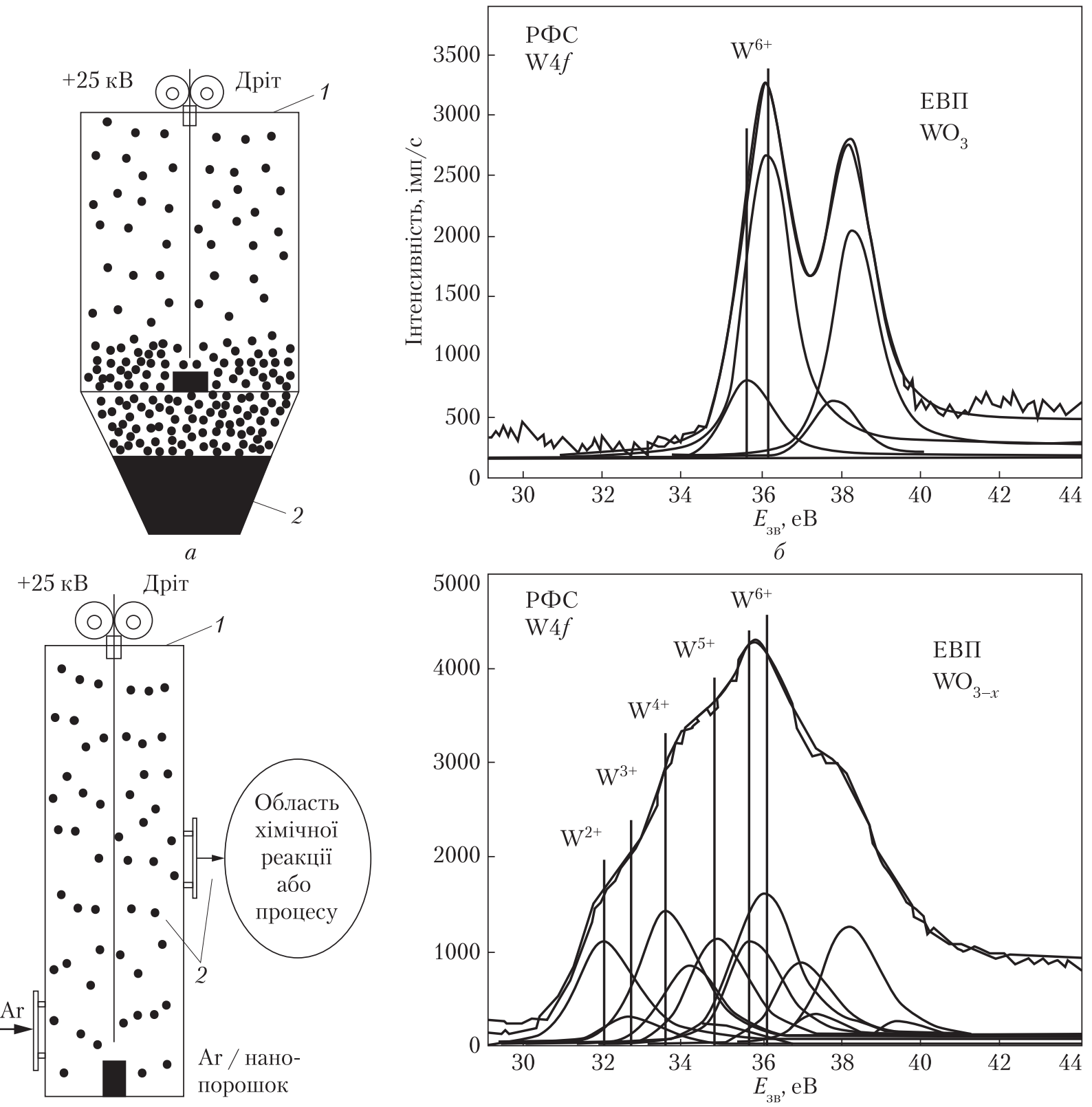

Puc. 1. Класична схема синтезу нанопорошків з використанням ЕВП ( $a: 1$ - вибухова камера, 2 - бункер 3 нанопорошком) та РФС W4 $f_{7 / 2}$-спектри нанопорошку вольфраму після пасивації киснем (б) і нова схема синтезу наноматеріалів з використанням ЕВП (в: 1 - вибухова камера, 2 - аерозоль нанопорошку в аргоні) та РФС W4 $f_{7 / 2}$-спектри нанопорошку вольфраму після його доставки в область реакції (2)

дослідження методами РФС, ПЕМ та СЕМ щойно синтезованих ЕВП нанопорошків на основі вольфраму та титану, визначення зарядових станів атомів і морфології поверхні.

На рис. 1, а проілюстровано класичну схему синтезу нанопорошків з використанням ЕВП, в якій після вибуху синтезований нанопорошок збирається в бункер 2 вибухової камери 1. При цьому в результаті релаксації дефектної структури і контакту наночастинок 3 ISSN 1025-6415. Допов. Наи. акад. наук Укр. 2021. № 4 


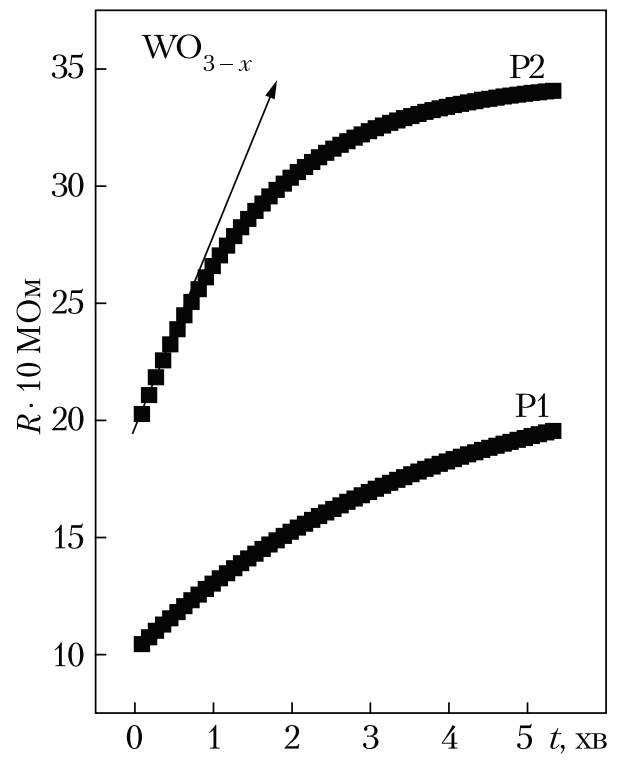

Puc. 2. Залежності електричного опору нанопорошку $\mathrm{WO}_{3-x}$ фракцій $\mathrm{P} 1$ та $\mathrm{P} 2$ від часу їх контакту з повітрям киснем відбуваються агломерація та окислення нанопорошків з втратою хімічно активних центрів поверхні. На рис. 1, б зображено $\mathrm{W} 4 f_{7 / 2}$-спектри нанопорошку вольфраму, синтезованого ЕВП в аргоні. Видно, що поверхня нанопорошку після пасивації киснем і кількох годин зберігання сформована виключно $\mathrm{W}^{6+}$-станами $\mathrm{WO}_{3}$, що характерно для триоксиду вольфраму, отриманого в рівноважних умовах хімічного синтезу.

На рис. 1, в проілюстровано нову схему синтезу наноматеріалів з використанням ЕВП, яка відрізняється тим, що синтезований нанопорошок, який після вибуху заповнює вибухову камеру (1) у вигляді аерозолю (2), доставляється в інертному газі в область зовнішнього синтезу протягом кількох десятків секунд або миттєво. На рис. 1, 2 зображено $\mathrm{W} 4 f_{7 / 2^{-}}$ спектри нанопорошку вольфраму, який після синтезу ЕВП в аргоні було доставлено в реальному часі в бокс з інертним газом і далі - у вакуумну камеру РФСспектрометра. 3 аналізу рис. 1, г випливає, що поверхня наночастинок містить значний внесок іонів металу зі зниженими ступенями окиснлення у вигляді $\mathrm{W}^{2+}-, \mathrm{W}^{3+}-, \mathrm{W}^{4+}-, \mathrm{W}^{5+}$ станів вольфраму, які є хімічно активними центрами.

На рис. 2 наведено залежності електричного опору щойно синтезованих в аргоні ЕВП нанопорошків $\mathrm{WO}_{3-x}$ різних за розмірами фракцій від часу їх контакту з повітрям. Збільшення початкового опору фракції Р2 пояснюється більшим питомим числом контактів між дрібними частинками. Зростання електроопору нанопорошків з часом відбувається внаслідок формування у наночастинок оксидної оболонки. Залежності мають експоненціальний характер внаслідок гальмування дифузії кисню в об’єм, що обумовлено збільшенням товщини оксидної оболонки. Видно (див. рис. 2), що вже за хвилину залежність опору для фракції Р2 починає відхилятися від лінійної, що вказує на формування початкової оксидної оболонки наночастинок і, відповідно, початок втрати їх поверхнею хімічно активних центрів. Саме тому використання синтезованих ЕВП нанопорошків в інших синтезах як надактивних прекурсорів хімічних реакцій необхідно проводити в реальному часі.

Таким чином, нанопорошки металів, синтезовані методом ЕВП в аргоні, які фактично є пірофорними, можуть бути використані як надактивні прекурсори в зовнішніх хімічних реакціях або процесах тільки в реальному часі - протягом кількох десятків секунд, без контакту між наночастинками для запобігання їх агломерації і без контакту з киснем. Це можливо, якщо їх доставка відбувається у вигляді стійкого аерозолю нанопорошків у інертному газі.

Із застосуванням нового методу синтезу наноматеріалів з використанням ЕВП вперше отримано новий тип плазмових нанодисперсних покриттів $\mathrm{WO}_{3-x}$ /нержавіюча сталь [5]. На рис. 3, $a-2$ наведено СЕМ-зображення $\mathrm{WO}_{3-x}$ /нержавіюча сталь покриттів. Для їх формування аерозоль щойно синтезованих ЕВП нанопорошків $\mathrm{WO}_{3-x}$ в аргоні було дос- 

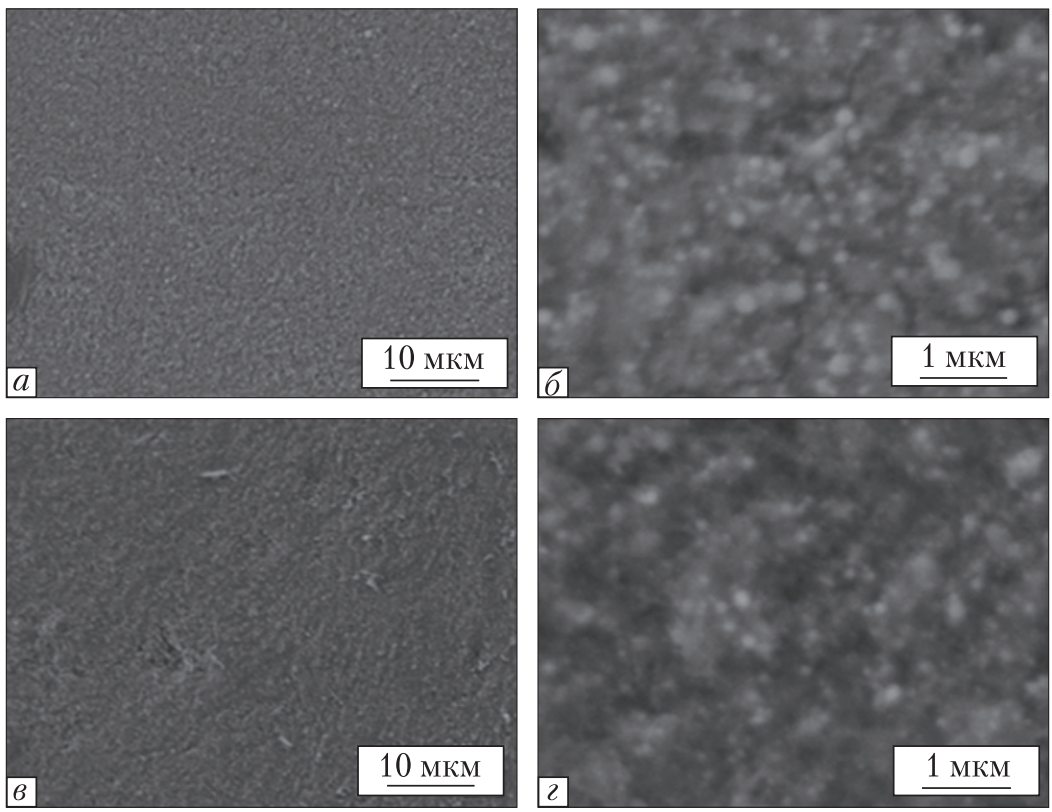

Puc. 3. СЕМ-зображення поверхні покриття $\mathrm{WO}_{3-x} /$ нержавіюча сталь; режим $\mathrm{Ar} / \mathrm{H}_{2}, I=24 \mathrm{~A}$, відстань під час напилення: $L=30$ мм $(a, \sigma)$, $L=40 \mathrm{Mм}(8, \imath)$

тавлено в область електричної дуги мікроплазмотрона. Видно, що в усіх випадках вдалося зберегти нанодисперсну структуру покриттів, які сформовано виключно з нанопорошку $\mathrm{WO}_{3-x}$. Це неможливо за класичними плазмовими технологіями, в яких для рівномірної доставки агломерованих нанопорошків в область дуги з нанопорошків формуються мікрогранули діаметром 20-100 мкм з використанням органічних зв'язуючих і проводиться їх подальший відпал при 1200-1400 ㄷ для видалення органічної складової [6-9]. При цьому відбувається агломерація наночастинок зі значною втратою наноструктури, їх забруднення карбідними фазами. У разі використання органічних розчинників, води або рідких прекурсорів покриття забруднюються гідроксидними сполуками, хлором і фтором. Все це істотно впливає на якість, зокрема, каталітичних покриттів.

Таким чином, вперше отримано плазмові оксидні каталітичні нанопокриття нового типу, без сторонніх домішок і зі збереженою в покриттях нанодисперсною структурою. За даними РФС поверхня покриттів $\mathrm{WO}_{3-x}$ /нержавіюча сталь містить активні центри у вигляді іонів металу зі зниженим ступенем окиснення та кисневі вакансії [5].

У цілому, за такою схемою використання ЕВП можна отримувати каталітично активні наноматеріали нового типу для розробки фотокаталізаторів, сенсорів, антимікробних покриттів, касетних каталізаторів на металевій гнучкій основі. Перспективним є формування нанодисперсних плазмових керамічних покриттів, які мають більш високі механічні характеристики внаслідок пластичності і є новим напрямком формування керамічних захисних покриттів.

Також із застосуванням нового методу синтезу наноматеріалів з використанням ЕВП вперше отримано нанодисперсні мезопоруваті плівки нового типу. Для формування наноплівок аерозоль щойно синтезованих ЕВП нанопорошків $\mathrm{TiO}_{2-x}$ або $\mathrm{TiO}_{2-x} / \mathrm{Ag}$ в ат- 

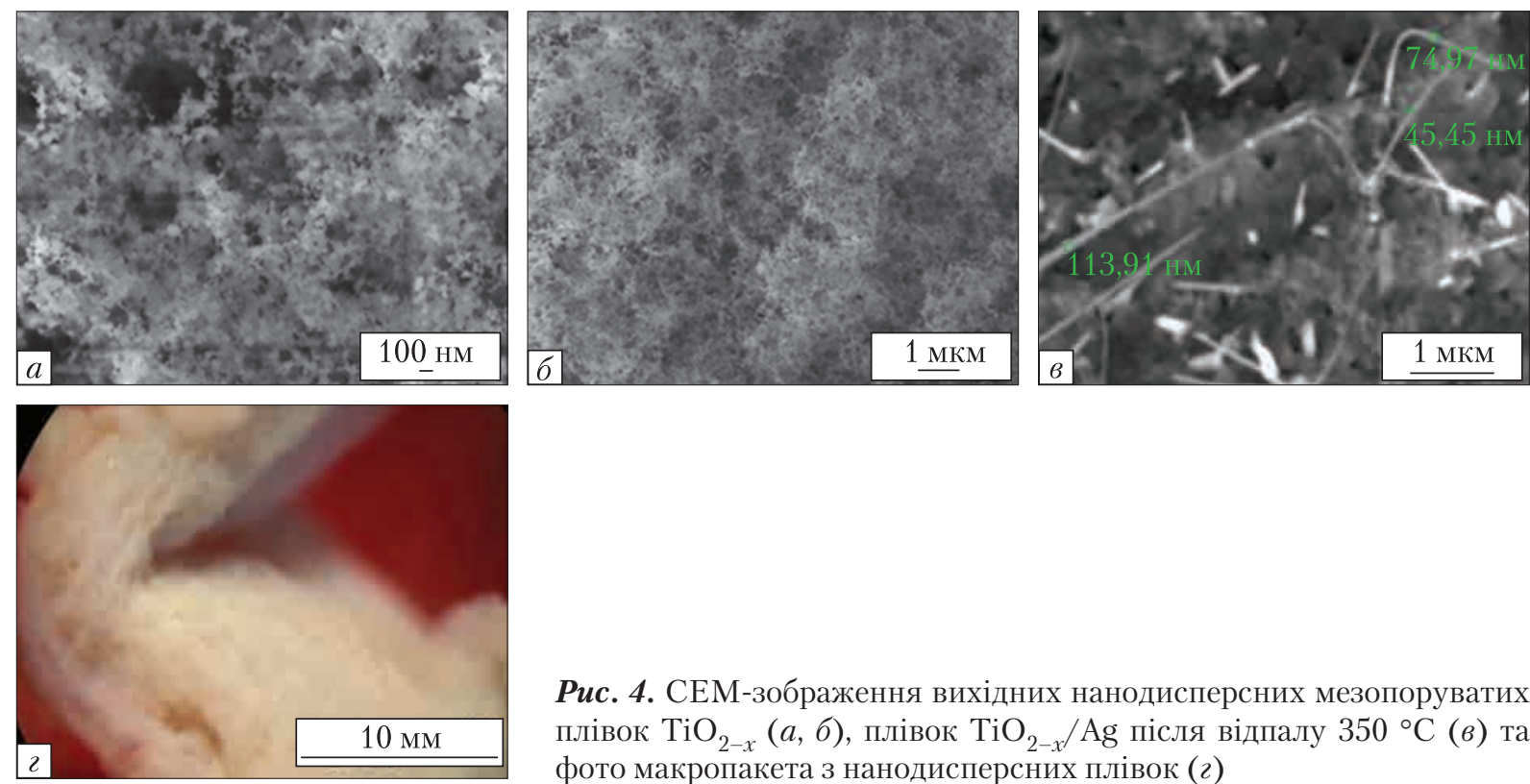

Puc. 4. СЕМ-зображення вихідних нанодисперсних мезопоруватих плівок $\mathrm{TiO}_{2-x}(a, \sigma)$, плівок $\mathrm{TiO}_{2-x} / \mathrm{Ag}$ після відпалу $350{ }^{\circ} \mathrm{C}($ ( $)$ та фото макропакета з нанодисперсних плівок (2)

мосфері сухого повітря було подано в область електростатичного зазору. На рис. 4, $a-8$ наведено CEM-зображення нанодисперсних мезопоруватих плівок, сформованих з $\mathrm{TiO}_{2-x}$ та $\mathrm{TiO}_{2-x} /$ Ag. Нанодисперсна структура в плівках збереглася (рис. 4, $a, 6$ ), вони складаються виключно зі з’єднаних між собою наночастинок $\mathrm{TiO}_{2-x}(30-60$ нм $)$ і одночасно це є однорідні за структурою макрооб'єкти (див. рис. 4, г). Такі наноматеріали неможливо отримати хімічними методами внаслідок наявності поверхневого натягу рідини в золях.

Формування плівок відбувається внаслідок самоорганізації заряджених наночастинок оксиду титану під дією електростатики через контакти між атомно-чистими поверхнями. Отримані наноматеріали не містять в собі шкідливих домішок, їх синтез відбувається без використання органічних та неорганічних зв’язуючих. У результаті формування з них активного елементу газового сенсора значно збільшується його питома поверхня зі збереженням заданого хімічного складу. Утворення плівок можливе як в електростатичному зазорі, так і на пласкій зарядженій поверхні.

На рис. 4, в наведено СЕМ-зображення плівки $\mathrm{TiO}_{2-x} / \mathrm{Ag}$ після відпалу при $350{ }^{\circ} \mathrm{C}$. Видно появу нановіскерів діаметром 45-110 нм, які можуть бути наслідком релаксації нерівноважної системи $\mathrm{TiO}_{2-x}-\mathrm{Ag}$. Приклади синтезу аналогічних наноплівок у літературі відсутні. Новий метод синтезу наноматеріалів дає можливість повністю зберегти в плівках нанодисперсну структуру, контролювати їх хімічний склад і скоротити кількість проміжних етапів синтезу порівняно з класичними методами [10].

Синтез нового типу наноплівок є перспективним для розробки активних елементів сенсорів, фотокаталізаторів та фотокаталітичних фільтрів.

За допомогою нового методу вдалося зменшити температуру проведення реакції синтезу $\mathrm{WS}_{2}$, завдяки використанню нанопорошків $\mathrm{WO}_{3-x}$ як надактивних прекурсорів.

Під час проведення реакції синтезу $\mathrm{WS}_{2}$ нанопорошок $\mathrm{WO}_{3-x}$ в аерозолі з аргоном було подано в область реакції на керамічну підкладинку, розташовану в кварцовій трубці. Також 
в область реакції було подано $\mathrm{H}_{2} \mathrm{~S}$ при $450{ }^{\circ} \mathrm{C}$ протягом 40 хв. Після синтезу зразок для видалення вільної сірки був очищений УЗ в бензолі.

За даними РФС у синтезованому $\mathrm{WS}_{2}$ зафіксовано три окремі фази, в яких значення енергії зв'язку W4f-, S2p-рівнів поверхневих атомів збігаються зі значеннями для нанокристалічних фаз модельного $\mathrm{WS}_{2}[11]$.

У результаті проведено низькотемпературний синтез дисульфіду вольфраму $\mathrm{WS}_{2}$ :

$$
\mathrm{WO}_{3-x}+3 \mathrm{H}_{2} \mathrm{~S} \rightarrow \mathrm{WS}_{2}+\mathrm{S}+3 \mathrm{H}_{2} \mathrm{O}\left(\mathrm{H}_{2} \mathrm{~S}, 450^{\circ} \mathrm{C}, 40 \text { хв }\right) \text {. }
$$

Температуру реакції (1) зменшено з 800 до 450 ㄷ․ Низькотемпературний синтез $\mathrm{WS}_{2}$ в умовах вакууму $\left(500{ }^{\circ} \mathrm{C}, 1\right.$ год) описано в [12].

Таким чином, розроблено новий метод синтезу наноматеріалів, в якому синтез нанопорошків методом ЕВП суміщено в часі з іншими синтезами та процесами з метою використання в них синтезованих нанопорошків у реальному часі як надактивних прекурсорів.

Вперше безпосередньо з нанопорошків отримано нові типи наноматеріалів: нанодисперсні каталітичні плазмові нанопокриття та мезопоруваті нанодисперсні плівки, в яких відсутні карбідні фази і домішки від органічних наповнювачів та прекурсорів. Доведено можливість використання синтезованих методом ЕВП нанопорошків як надактивних прекурсорів хімічних реакцій.

Розроблено і виготовлено оригінальне обладнання ЕВП, на основі якого можливе створення компактних установок із синтезу нових типів наноматеріалів для профільних інститутів НАН України.

Новий метод синтезу наноматеріалів з використанням ЕВП, на відміну від класичного, можна включати в неперервні промислові ланцюги.

Показано, що розроблений метод синтезу наноматеріалів є новим інструментом вирішення задач в області нанотехнологій і може бути використаний для розвитку інноваційних секторів економіки України.

\section{ЦИТОВАНА ЛІТЕРАТУРА}

1. Гусев А.И. Наноматериалы, наноструктуры, нанотехнологии. Москва: Физматлит. 2005. 410 с.

2. Kotov Yu.A. Electric explosion of wires as a method for preparation of nanopowders. J. Nanoparticle Res. 2003. 5. P. 539-550. https://doi.org/10.1023/B:NANO.0000006069.45073.0b

3. Nazarenko O. Nanopowders produced by electrical explosion of wires. Proceedings of European Congress of Chemical Engineering (ECCE-6) (Copenhagen, 16-20 Sept. 2007). Copenhagen, 2007.

4. Кордубан О.М., Огенко В.М., Крищук Т.В. Проблеми розвитку методу рентгенівської фотоелектронної спектроскопії в Україні. Укр. хім. журн. 2021. 87, № 1. С. 41-50. https://doi.org/10.33609/2708129Х.87.01.2021.41-50

5. Кордубан О.М., Крищук Т.В., Трачевський В.В., Медведський М.М. Формування плазмових нанодисперсних покриттів на основі електровибухових нанопорошків оксиду вольфраму. Металофіз. новітні технол. 2021. 43, № 1.С. 47-58. https://doi.org/10.15407/mfint.43.01.0047

6. Yang J., Jia J., Li X., Lu C., Feng X. Synergistic lubrication of $\mathrm{Ag}$ and $\mathrm{Ag}_{2} \mathrm{MoO}_{4}$ nanoparticles anchored in plasma-sprayed YSZ coatings: Remarkably-durable lubricating performance at $800^{\circ} \mathrm{C}$. Tribol. Int. 2021. 153. 106670. https://doi.org/10.1016/j.triboint.2020.106670

7. Xie S., Song C., Yu Z., Liu S., Lapostolle F., Klein D., Deng C., Liu M., Liao H. Effect of environmental pressure on the microstructure of YSZ thermal barrier coating via suspension plasma spraying.J. Eur. Ceram. Soc. 2021. 41, Iss. 1. P. 535-543. https://doi.org/10.1016/j.jeurceramsoc.2020.08.022 
8. Song C., Wang Y., Fan X., Xie S., Liu M., Zhou K., Deng C., Deng C., Liao H. Microstructure and mechanical property of dense yttria-stabilized zirconia coating fabricated by an axial bi-cathode plasma torch under very low pressure. Ceram. Int. 2020. 46. P. 9507-9511. https://doi.org/10.1016/j.ceramint.2019.12.212

9. Huang H., An Y., Hu X., Wu D., Cao H., Zhang X., Qiao J., Liu H. A plasma sprayed superhydrophobic coating prepared with $\mathrm{Al} @ \mathrm{WO}_{3}$ core-shell powder and photocatalytic degradation performance. Surface and Coatings Technology. 2019.369. P. 105-115. https://doi.org/10.1016/j.surfcoat.2019.04.055

10. Петрик І.С., Келип О.О., Воробець В.С., Смірнова Н.П., Фролова О.К., Оранська О.І., Колбасов Г.Я., Єременко А.М. Синтез, оптичні, фото- та електрокаталітичні властивості нанорозмірних плівок $\mathrm{TiO}_{2}$, модифікованих іонами перехідних металів. Хімія, фізика та технологія поверхні. 2011. 2, № 4. C. $436-442$.

11. Shpak A.P., Korduban A.M., Kulikov L.M., Kryshchuk T.V., Konig N.B., Kandyba V.O. XPS studies of the surface of nanocrystalline tungsten disulfide. J. Electron Spectrosc. Rel. Phenom. 2010. 181, Iss. 2-3. P. 234-238. https://doi.org/10.1016/j.elspec.2010.05.030

12. Morrish R., Haak T., Wolden C.A. Low temperature synthesis of $n$-type $\mathrm{WS}_{2}$ thin films via $\mathrm{H}_{2} \mathrm{~S}$ plasma sulfurization of $\mathrm{WO}_{3}$. Chem. Mater. 2014. 26, № 13. P. 3986-3992. https://doi.org/10.1021/cm501566h

Надійшло до редакції 02.06.2021

\section{REFERENCES}

1. Gusev, A. L. (2005). Nanomaterials, nanostruktures, nanotechnologies. Moscow: Fizmatlit (in Russian).

2. Kotov, Yu. A. (2003). Electric explosion of wires as a method for preparation of nanopowders. J. Nanoparticle Res., 5, pp. 539-550. https://doi.org/10.1023/B:NANO.0000006069.45073.0b

3. Nazarenko, O. (2007, September). Nanopowders produced by electrical explosion of wires. Proceedings of European Congress of Chemical Engineering (ECCE-6), Copenhagen.

4. Korduban, O. M., Ogenko, V. M. \& Kryshchuk, T. V. (2021). Problems of development of the method of X-ray photoelectron spectroscopy in Ukraine. Ukr. Chem. J., 87, No. 1, pp. $41-50$ (in Ukrainian). https://doi. org/10.33609/2708-129X.87.01.2021.41-50

5. Korduban, A. M., Kryshchuk, T. V., Trachevskii, V. V. \& Medvedskij, M. M. (2021). Formation of plasma nanodisperse coatings based on electric explosive nanopowders of tungsten oxide. Metallofiz. Noveishie Tekhnol., 43, No. 1, pp. 47-58 (in Ukrainian). https://doi.org/10.15407/mfint.43.01.0047

6. Yang, J., Jia, J., Li, X., Lu, C. \& Feng, X. (2021). Synergistic lubrication of Ag and $\mathrm{Ag}_{2} \mathrm{MoO}_{4}$ nanoparticles anchored in plasma-sprayed YSZ coatings: Remarkably - durable lubricating performance at $800{ }^{\circ} \mathrm{C}$. Tribol. Int., 153, 106670. https://doi.org/10.1016/j.triboint.2020.106670

7. Xie, S., Song, C., Yu, Z., Liu, S., Lapostolle, F., Klein, D., Deng, C., Liu, M. \& Liao, H. (2021). Effect of environmental pressure on the microstructure of YSZ thermal barrier coating via suspension plasma spraying. J. Eur. Ceram. Soc., 41, Iss. 1, pp. 535-543. https://doi.org/10.1016/j.jeurceramsoc.2020.08.022

8. Song, C., Wang, Y., Fan, X., Xie, S., Liu, M., Zhou, K., Deng, C., Deng, C. \& Liao, H. (2020). Microstructure and mechanical property of dense yttria-stabilized zirconia coating fabricated by an axial bi-cathode plasma torch under very low pressure. Ceram. Int., 46, pp. 9507-9511. https://doi.org/10.1016/j.ceramint. 2019.12.212

9. Huang, H., An, Y., Hu, X., Wu, D., Cao, H., Zhang, X., Qiao, J. \& Liu, H. (2019). A plasma sprayed superhydrophobic coating prepared with $\mathrm{Al} @ \mathrm{WO}_{3}$ core-shell powder and photocatalytic degradation performance. Surface and Coatings Technology, 369, pp. 105-115. https://doi.org/10.1016/j.surfcoat.2019.04.055

10. Petrik, I., Kelyp, O., Vorobets, V., Smirnova, N., Frolova, O., Oranska, O., Kolbasov, G. \& Eremenko, A. (2011). Synthesis, optical, photo- and electrocatalytic properties of nanosized TiO2 films modified with transition metal ions. Him., Fiz., Tehnol. Poverhni, 2, No. 4, pp. 436-442 (in Ukrainian).

11. Shpak, A. P., Korduban, A. M., Kulikov, L. M., Kryshchuk, T. V., Konig, N. B. \& Kandyba, V. O. (2010). XPS studies of the surface of nanocrystalline tungsten disulfide. J. Electron Spectrosc. Rel. Phenom., 181, Iss. 2-3, pp. 234-238. https://doi.org/10.1016/j.elspec.2010.05.030

12. Morrish, R., Haak, T.\& Wolden, C. A. (2014). Low temperature synthesis of $n$-type $\mathrm{WS}_{2}$ thin films via $\mathrm{H}_{2} \mathrm{~S}$ plasma sulfurization of $\mathrm{WO}_{3}$. Chem. Mater., 26, No. 13, pp. 3986-3992. https://doi.org/10.1021/cm501566h

Received 02.06.2021 
O.M. Korduban ${ }^{1}$, https://orcid.org/0000-0003-4401-0203

T.V. Kryshchuk ${ }^{1}$, https://orcid.org/0000-0001-6527-2021

M.M. Medvedskij ${ }^{2}$

${ }^{1}$ V.I. Vernadsky Institute of General and Inorganic Chemistry of the NAS of Ukraine, Kyiv

${ }^{2}$ Main Astronomical Observatory of the NAS of Ukraine, Kyiv

E-mail: akord.imp@gmail.com

\section{A NEW METHOD FOR THE SYNTHESIS OF NANOMATERIALS FOR THE NEEDS OF NANOTECHNOLOGIES}

A new method for the synthesis of nanomaterials using the an electric explosion of wires (EEW) has been developed. In it, the process of nanopowder synthesis is combined in time with other syntheses in order to use EEW nanopowders as superactive precursors of real-time reactions.

For the first time, new types of catalytic plasma nanocoatings $\mathrm{WO}_{3-x}$ /stainless steel were obtained directly from nanopowders. steel and mesoporous photo- and electrocatalytic nanodisperse films $\mathrm{TiO}_{2-x}, \mathrm{TiO}_{2-x} / \mathrm{Ag}$. In nanomaterials of a new type, the nanodisperse structure is completely preserved, and organic components are not used in their production. Due to the use of EEW of $\mathrm{WO}_{3-x}$ nanopowders as superactive precursors, the reaction temperature of the $\mathrm{WS}_{2}$ synthesis $\mathrm{WO}_{3-x}+3 \mathrm{H}_{2} \mathrm{~S} \rightarrow \mathrm{WS}_{2}+\mathrm{S}+3 \mathrm{H}_{2} \mathrm{O}$ was reduced from 800 to $450{ }^{\circ} \mathrm{C}$. It is shown that the proposed method of synthesis of nanomaterials is a new tool for solving the problems in the field of nanotechnologies.

Keywords: electric explosion of wires, EEW, nanopowders, plasma nanocoatings, nanodisperse films, XPS. 